Fall 2006

\title{
Cubanas refugiadas: A Critical examination of the social contexts and formal English language learning opportunities of four newly- arrived immigrant women
}

John S. Butcher

University of Nevada, Las Vegas

Jane S. Townsend

University of Florida

Follow this and additional works at: https://digitalscholarship.unlv.edu/jpme

\section{Repository Citation}

Butcher, John S. and Townsend, Jane S. (2006) "Cubanas refugiadas: A Critical examination of the social contexts and formal English language learning opportunities of four newly-arrived immigrant women," Journal of Praxis in Multicultural Education: Vol. 1: No. 1, Article 5.

DOI: 10.9741/2161-2978.1019

Available at: https://digitalscholarship.unlv.edu/jpme/vol1/iss1/5

This Article is protected by copyright and/or related rights. It has been brought to you by Digital Scholarship@UNLV with permission from the rights-holder(s). You are free to use this Article in any way that is permitted by the copyright and related rights legislation that applies to your use. For other uses you need to obtain permission from the rights-holder(s) directly, unless additional rights are indicated by a Creative Commons license in the record and/ or on the work itself.

This Article has been accepted for inclusion in Journal of Praxis in Multicultural Education by an authorized administrator of Digital Scholarship@UNLV. For more information, please contact digitalscholarship@unlv.edu. 


\title{
Cubanas Refugiadas: A Critical Examination of the Social Contexts and Formal English Language Learning Opportunities of Four Newly-Arrived Immigrant Women
}

\begin{abstract}
John S. Butcher and Jane S. Townsend
Angelica sat quietly thumbing her dictionary. She turned her head when a classmate tapped her on the shoulder to whisper a question about the grammar worksheet they were working on. Marina, in her seat across the room, was nodding her head as another classmate explained a vocabulary word in Spanish. In another classroom, Dora stared down at her book as her teacher urged the class to silence. Dora spent the next 50 minutes mimicking the sounds the teacher modeled as he read verbatim from the text dialogues. Elsewhere, Damaris whispered something to the woman sitting next to her at the table in their makeshift classroom on the stage. She nodded at her classmate's response and squinted at the board. Damaris was delighted to enter new vocabulary items into her notebook. Her facial expressions displayed the intensity of her work. Having arrived in the U.S. as Cuban refugees in 2000 or early 2001, Angelica, Dora, Marina, and Damaris were beginning their English language studies. They attended the lifeskills, performance-based foundations English to Speakers of Other Languages (ESOL) classes of The Language School, an adult education center located in the heart of the historical Cuban exile enclave in Miami, Florida (cf. García 1996; Portes \& Bach 1985). (All names are pseudonyms.)

The purpose of this study was to explore the influences of social contexts on the four Cuban refugee women's school attendance and on their second language learning opportunities as they began their first formal educational experiences in the U.S. Learner-centered researchers such as Menard-Warick (2005) state the

John S. Butcher is currently Assistant Professor of English Language Acquisition in the Department of Curriculum \& Instruction at UNLV. For18 years he had been an adult ESOL teacher, curriculum writer, and in-service trainer in Miami-Dade County Public Schools. He was also a member of the Florida State Task Force for Adult ESOL. Jane S. Townsend is Associate Professor of English Education in The School of Teaching and Learning at the University of Florida. Her research and teaching specialties include issues of first and second language acquisition, inquiry, and the arts and literacy.
\end{abstract}


need to examine the complexities of language learning within communities (p. 167). As researchers, we were interested in the opportunities each woman had for learning and using English during her class attendance time through descriptive analyses of what actually occurred in the classrooms of each woman over the course of two trimesters. Multiple studies have shown that gender differences do exist in language learning and that there is a need to explore more thoroughly the influences of gender on language teaching and learning (Schwarte 2001). Our interests in this study centered on three questions:

- What were contextual influences that framed and shaped the four women's experiences of learning English in their ESOL classrooms?

- What were their classroom opportunities for language learning?

- What classroom environmental factors supported their learning opportunities?

By contextual influences, we mean those factors present in the participants' lives that frame their perspectives of learning as newly-arrived immigrants and as students in their first ESOL classroom placements. Norton-Peirce (1995) points to the lack of Second Language Acquisition (SLA) theory that integrates second language learners and their learning contexts. Our work is informed by constructivist theory in SLA that values an adult learner's life experiences and knowledge as the foundation and springboard of instruction (Cummins 1983, Krashen 1981). Ideally, students and teachers are partners in the learning process where the classroom is "a social space, and this means a place where interaction is valued, not simply tolerated" (Lindfors, 1999, p. 222).

\section{Review of Related Literature}

Gender as Site of Inquiry

We are interested in the influences of adult education classes in women's learning, in their professional goals, and in their decisions to attend school or not. We chose to study women's language learning contexts exclusively, without comparison to men's learning issues, because of two key assumptions drawn from feminist research: (a) women's learning must be understood and valued in its own right, and (b) women's learning must be understood within a broad social context that encompasses social determinants of gender roles and norms (Hayes \& Flannery 2001, p. xii).

An emerging body of scholarship focuses solely on immigrant women's language learning (Katasse 1994; Norton-Peirce 1995; Menard-Warwick 2005; Rockhill 1987; Rockhill \& Tomic 1995). However, most related studies we have reviewed either did not address gender or compared women's and men's experiences and behaviors in educational settings. In the past, when research in 
adult education has focused on perspectives of women, findings have portrayed them as deficient or marginalized collaborative learners who must cope with new social roles (Hayes \& Flannery 2001). In related research, studies of refugee women's concerns in resettlement, in which language learning is a factor, form a growing body of work within the field of psychology (Boyd 2001; Espín 1999; Saldaña 1992).

According to Bem (1993), "What virtually all the women-centered theorists have seen as a woman's special virtue is her ability to easily transcend the many isolated units and artificial polarities that men are said to almost compulsively invent" (p. 128). The participants in this study demonstrated such multidimensionality in their experiences and identities as mothers, daughters, spouses, workers, all complicated by living as newcomers to a politically powerful, longstanding Cuban exile community.

Feminist theory situates identity formation and language learning in social and historical contexts. On a daily basis, learners must dynamically relate to the power structures of the target language society, the learning environment, and the opportunities for speaking and negotiating one's place. Second language learners, especially female newcomers to a new, dominant male culture, negotiate complex social roles, contexts, and identities (Townsend \& Fu, 2001). Tisdell (1993) criticizes adult education classroom practices and curriculum as being driven by white male, middle class values that might not be in the interests of women, and especially women from minority populations. Tisdell's criticism of adult learning environments is a reaction to the reproduction of male power and the oppression of women inherent in workforce and domestic labor settings. She claims that men's experiences and goals in adult learning are more often validated than are those of minority women.

Women's participation in adult education is a complex phenomenon (Gómez, 2000; Losey 1995). Perceived obligations to domestic, familial, and occupational duties are among many forces that might positively, or negatively, influence a woman's decisions to attend school and to continue doing so. In the historical context of the Miami Cuban exile community, adult female refugees, who often found work within the Spanish-speaking community, did not attend English classes as frequently as males (Rogg, 1974). Portes and Bach (1985) reported that "between 1976 and 1979, while just less than one third of the [Cuban] men attended class, only $21 \%$ of the [Cuban] women received similar formal instruction" (p. 179). Since the 1970s, changes in labor markets and technological advances have forced many people to seek specialized education (Gómez 2000, Portes \& Bach 1985). In the analysis of data by gender in her study of adult education participation, Gómez (2000) found more women than men tend to make the decision to attend on their own and more men than women participated on the suggestion of their employer (p. 215). She also found that women rely on information and recommendations from neighbors, friends, and family members as they consider their return to formal education settings. Luttrell (1989), in her study of 30 working-class women of color, argued that there are profound reasons for women to participate in schooling. Luttrell found that 
[T]heir identities are already embedded in cultural, community, and work relationships, yet their desire to expand, perfect, or contradict the work they do as women underlies their participation in school (p. 34).

Rockhill (1987) in her study of 50 Hispanic women in Los Angeles, found that many women express the desire to attend English classes. They first enroll in such classes soon after they arrive from another country. Women attending adult education programs are most likely to be enrolled in the lower skills classes. Gómez agrees. "The more basic the level of the course, the more women were over-represented among the participants" (Gómez 2000, p. 217). Unfortunately, despite effort and desire, many female students discontinue their studies during their lower levels of ESOL enrollment.

They explain stopping in terms of the enormous pressures of their daily lives, including resistance at home. They talk about worry, anxiety, too much on their minds, and feeling too old to concentrate upon the difficult and timeconsuming endeavor of learning the language (Rockhill 1987, p. 163).

Rockhill argues that the rates of women's attendance are proportionate to the extent that institutional factors support their participation and learning. What is equally important, she found, is that a woman can begin to identify herself as a learner in school when she has the chance to interact with other women in class. This finding seems to suggest there is strength, inspiration, and opportunity to learn in a community of learners.

Psychologist Espín (1999) addressed the complexities behind classroom interactions as learners attempt to learn the language, and acquire the skills to negotiate new cultural spheres.

The immigrant learns to "live in two languages" at the same time she learns to live in two social worlds. Learning to live in a new language is not merely an instrumental process; it is not a neutral act. (Espín 1999, p. 134.).

Espín explains that both concern for freedom of movement and their acceptance by the dominant U.S. society seemed to reflect women's hope for greater independence and transforming identities. Norton-Peirce (1995) agrees with Espín.

When language learners speak, they are not only exchanging information with target language speakers but they are constantly organizing and reorganizing a sense of who they are and how they relate to the social world. Thus an investment in the target language is also an investment in the learner's own social identity, an identity which is constantly changing across time and space (p. 17).

Learning the dominant language can be seen as an investment in oneself, one's family, and one's social community. However, for many women, initial language learning comes from a need for self defense in the threatening 
borderland between their home culture and the newly entered environment. In her study of female Spanish-speaking immigrants, Klassen (1987) found that some language learners wanted to learn English as a means of defense in their daily lives. It is important to point out that when Spanish speakers use the cognate, defender (to defend oneself), the meaning in not limited to situations of conflict, but can extend to explaining one's agency, opinion, or decision. "Initial efforts to learn the language are framed in terms of self-defense, of survival" (cited in Rockhill, 1987).

Coming to School: Research in Women's Participation in Adult ESOL Learning Contexts

Reality stands in contrast to stated goals of Adult ESOL teaching and learning; self-defense issues and women's language-learning investment are clearly not the focus of Adult ESOL in general. Most language teaching and materials in ESOL programs are organized into instructional units to teach the language of coping with social power structures as they exist. The "client," as a student enrolled in Florida adult education is called, receives language instruction that is embedded, according to state-established goal competencies, in cultural, social, and political spheres of the community and often in a lower wage workplace (FL DOE 2001a). Such a curriculum bias seems to validate Espín's (1999) observation that language learning is not a neutral act of instrumentality: "It implies being immersed in the power relations of the specific culture that speaks the specific language" (p. 134). The cultural aims and definition of "empowerment" in Adult ESOL in the last several years have been recast to fulfill economic mandates to teach specific language and behaviors exclusively aligned with labor interests and the greater consumer-oriented society.

Whereas labor and consumer language has become the framework of Adult ESOL curriculum content, Rockhill (1987) sharply condemns reliance on such a curriculum because, in her view, it does a disservice to female learners:

To frame literacy in terms of equality of opportunity, rights, or empowerment is absurd...in a gendered society where conception of rights is alien to women who have been told all their lives that they must obey and care for others (p. 165).

She suggests that women learners would be better served if researchers sought answers to how language in general enters their everyday lives and selfdefinitions. What does learning language mean to women and what is necessary to them?

\section{Women in the Cuban Exile Context}

Latina women in particular are regarded as virtuous if they demonstrate humility and selflessness in their relationships with family and community (Anzaldúa 1997; Zentella 1997). This attitude does not indicate passivity, however. Anzaldúa explains that kinship affects powerful forces on women's (and men's) gendered lives within the Hispanic cultural sphere. The obligations framed in 
kinship often define Latinas' identities and give rise to the pressures behind their daily struggles, an almost universal notion accepted as part of day-to-day living. From a Cuban exile perspective, Mujerista theologian Isasi-Díaz (1996) explains that Cuban women's lives in exile follow a daily struggle of identity and liberation referred to as, "lo cotidiano" (the daily [struggle]). Lo cotidiano refers to daily life experiences that constitute Cuban women's realities and how they might characterize actions, conversations, norms, social roles, and themselves (p. 67). The experiences of daily life are shared among the members of an individual's social network as illustrated by the flexible and elastic "sphere of influence" (Peck 1986, p. 275). As Isasi-Diaz explains:

Lo cotidiano points to "shared experiences," which I differentiate from "common experience." "Shared experiences" is a phrase that indicates the importance differences play in lo cotidiano. On the other hand, "common experience" seems to mask differences, to pretend that there is but one experience, one way of knowing for all Hispanic women (p. 68).

The philosophy behind Isasi-Díaz's description of lo cotidiano, or daily struggle (la lucha, the struggle) highlights the agency that Cuban women find and locate in their own lives lived in exile space and historical context. Indeed, the common Cuban cliché, "Hay que seguir luchando" (Ya gotta keep struggling!) surfaced in quotes repeatedly in the study data. As if to link la lucha with women's resistance to oppression, Butler (1993) points out that personal agency implicates the individual in the relations of power that she seeks to oppose (p. 123). Cuban exile educator, J. González (1997), illustrates both Butler's and Isasi-Díaz's point from her own exile perspective.

Not only did we have to watch out for our own survival, but we were also responsible for serving to support boyfriends, husbands, brothers, and fathers. With that lack of defined direction, we began planning our lives as women. Quickly, the rules of the game changed. [that is, "in exile"- our clarification. Translated by JSB.] (p. 39).

Within the relationships constructed by lo cotidiano, Cuban women judge their own "personal understandings, aspirations, ambitions, projects, and goals in their lives" (p. 71) usually in relation to their obligations to others.

\section{Method}

Data collection took place over a period of seven months during our participants' first two trimesters of formal English language learning in the U.S. The field observations began in October 2001 and concluded in April 2002 and data collected during that time were sufficient to answer the research questions. We chose a qualitative case study methodology in order to focus on the learners' priorities and interpretations of their environment situated in the interrelation between the participants' learning experiences and the contexts that surrounded them as mothers, wives, and workers in a new country (McCracken 1988). In case studies, data sources include not only interview and observation, but also 
analysis of documents, including, in this study, writing samples, and other discourse samples produced by the participants (Dörnyei 2001, p. 239). The data collection took place in the natural settings of the respective classrooms, where we tried not to interfere in the teaching and learning, because according to McDonough \& McDonough (1997), "a naturalistic observation would need as its database the everyday lesson with its usual participants in real time..." ( $p$. 114). We maintained participant/observer records in four forms as recommended by Spradley $(1979,1980)$ : the verbatim or raw data account of observations; an expanded account transcribed into field observation protocols; a research journal; and a running record of preliminary analysis.

Additional data for this qualitative study were provided by transcripts of two, 45-min. audio-recorded interviews in Spanish with each of the four women, conversations and observation field notes collected during at least three of their respective classes, three videotaped class sessions for each participant lasting about 45 minutes, and photocopied pages from their notebooks over the course of two trimesters. Three of the four women participated in three audio and videotaped focus discussion sessions in Spanish with the female Cuban refugee assistance coordinator at the school site, without the presence of a researcher. Protocols for the discussion sessions covered topics regarding the women's perceptions of learning opportunities in their classrooms, language learning ideologies, domestic and work pressures, and immigration and family issues. We sought the coordinator's assistance because she was a native speaker of Cuban Spanish and had been a Cuban refugee herself when she arrived in Miami in the 1960s. Her gender was also a consideration because we thought the participants might be more forthcoming in their conversations with her rather than with John, who - fluent in Spanish - conducted the field research of interviews, classroom observations, transcriptions, and translations.

Analysis of the data proceeded from the start, first in transcribing and translating interviews and remarks from the field notes from Spanish into English. After transcribing the audio and video recordings, we were able to conduct member checks with the participants and the coordinator. Any questions regarding the translations were presented to the participants for clarification. Several times we consulted the refugee assistance coordinator who had facilitated the conversation sessions in order to make sense of content and idiomatic expressions. The field researcher and the participants developed rapport over the period of the study and collaborated in the making of meaning through negotiation and dialogue. We believe the native-language transcription and member checks strengthened the data analysis.

We employed a constant comparative method of analyzing all data, not only focusing on the individual, but also looking for patterns of experience and context across the four cases. Triangulation of the data sources supported the findings of the study based on the comparisons of the recorded and transcribed conversations and videotapes, field note entries, and interpretation of the participants' written work taken from their notebooks. Member checks were ongoing throughout the study. John sat near each participant in her respective 
classes and was able to ask her questions about her activities as well as to confirm or discount initial interpretations.

\section{Findings}

Angelica, Marina, Dora, and Damaris

What were the contextual influences that framed and shaped the four women's experiences of learning English in their ESOL classrooms? First, the participants in the study shared certain similar life experiences and formative processes as they were growing up in Cuba influenced by the ideology of $L a$ Revolución. Historical influences were evident in the women's reasons for attending ESOL classes. All four had grown up in the social and educational systems of revolutionary Cuba where women's equality was treated ambivalently. In these women's lives, agency and self-determination were encouraged by the Revolutionary government's initiatives of equality of opportunity for women in most careers and workplaces. However, during the same time, women were charged with the domestic and reproductive duties of household management and childcare for the success of the Revolution (Guerra 2001). Women claimed most of the responsibility for family survival in "la lucha cotidiana" (the daily struggle) to "resolver" (get by) or make do with the shortage of food and supplies on the island (Isasi-Díaz 1996).

For clarity and reference, we have listed the personal data of each participant in Table 1 below. Overall, the participants' personal histories in Cuba were rooted in the revolutionary rhetoric and educational opportunities that proclaimed the goal of equality in all social structures. In their interviews, the four women spoke about similar life experiences that came about from Cuban government policy changes occurring over the course of their youth.

Further, the data revealed that social networks in Cuba and in Miami, sources of support, professional aspirations, matrimony and maternity formed the contexts of the four women's choices to enroll in the school. Their contexts were further complicated by their own uncertain expectations of their new lives in Miami and the overwhelming task of learning a new language. The women (a) negotiated pressure from spouses, (b) assisted their children in Cuba financially through remittances, (c) attempted to make sense of the uncertainties of crossing cultural and linguistic borders, and (d) anticipated eventual acceptance within the greater English-speaking society.

On a personal level, appreciation of support from established family and friends already settled in the Miami Cuban exile enclave was among the immigration factors that Angelica, Marina, Dora, and Damaris held in common. All four entered an exile space, their new surround, where as Cuban entrants they had deep historical connections. It is typical that those who came before provide the first line of support for newcomers upon arrival. Immigration and refugee researchers Zolberg, Suhrke, and Aguayo (1989) confirm the positive role of personal connections and, as could be expected, all four women spoke of 
the debt they owed to those in their families and social networks who, having left Cuba, had since established themselves successfully in Miami. "Support" is not only considered in material or financial means, but also, for the participants in the study, emotional and informational. Their familial connections and personal aspirations led the women to enroll at The Language School, possibly their first contact with a community-based institution in the U.S. The four women's experiences, situated as they were in the historical space of the enclave, extended to the school for English language instruction, as well as to the social service program for the counseling and material support they received there.

The four women came to school five days, 12.5 hours a week to learn English. Reasons for their attendance varied depending on their interests, educational backgrounds, and their social and familial surrounds. The observations of Angelica, Marina, Dora, and Damaris in their beginning ESOL classes revealed several areas of concern for their language learning. We found that their primary reasons for English language learning were based in their need to assist their children - most of whom remained in Cuba - placing their children's welfare and future above their own concerns. They felt that English language learning was a key to earning money for remittances to support their children who were awaiting visas to come to the U.S.

Secondary influences on their school attendance included responding to pressure from spouses, sensing limitations to their social and geographic movement based on perceived language barriers, and re-entering a profession. Angelica, Dora, Marina, and Damaris were immersed in a transnational identity development through interactions with family members and friends who lived in the Miami Cuban exile enclave. For them, self-definition was always evident when they spoke of both the historical time in which they were living and their current responsibilities in the complex interwoven life contexts surrounding them (Cole 1996). In contrast, during their class time, there appeared to be little or no attention to their personal needs or interests. Even before beginning their studies, the women individually encountered instances where their gender appeared to limit their vocational choices when a male counselor sought to place each of them in a Spanish-language Child Care training class.

In both Dora's and Marina's cases, they attended the school with their husbands, both of whom exerted pressure on their wives to learn English. Their spouses influenced their daily attendance positively, but Marina did not return to school for the second trimester, citing her domestic responsibilities and the pressures of her employment at a local supermarket. Damaris, the only participant whose child lived with her, received encouragement and inspiration from that daughter in Miami. The women's stated reasons for attendance reveal much about their investment in learning English (Norton-Peirce 1995).

With their varied reasons to learn English, the women sought out the school as a place of learning. However, their opportunities for learning were limited by the institutional need to meet state-mandated curriculum performance standards. 
Journal of Praxis in Multicultural Education, Vol. 1, No. 1 [2010], Art. 5

Table 1. Participants' Personal Data.

\begin{tabular}{|c|c|c|c|c|}
\hline 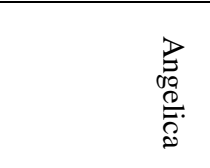 & ְ. & 㞼. & 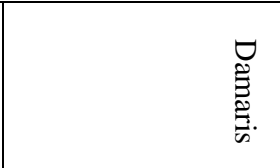 & 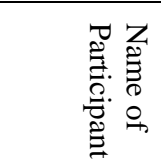 \\
\hline u & $\vec{N}$ & $\vec{b}$ & $\underset{\infty}{\infty}$ & 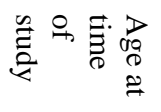 \\
\hline 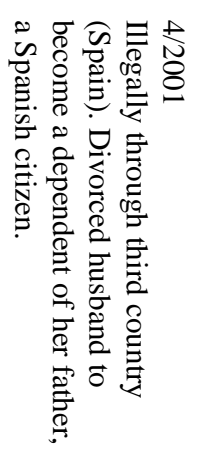 & 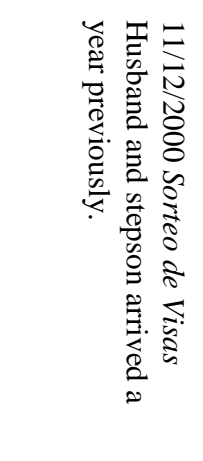 & 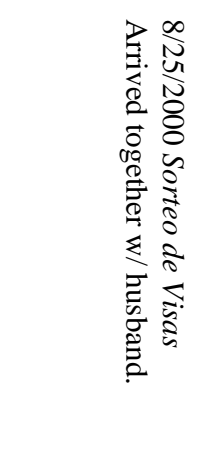 & 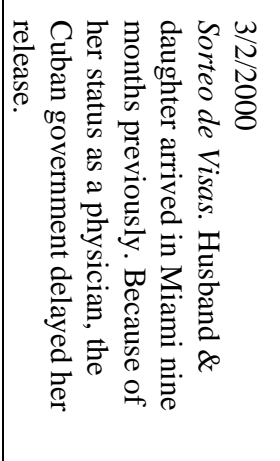 & 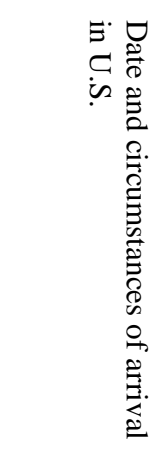 \\
\hline 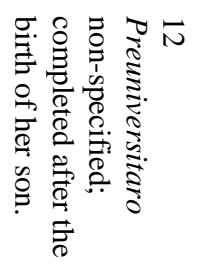 & 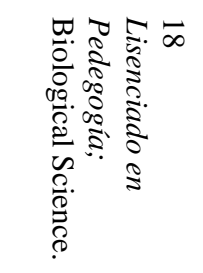 & 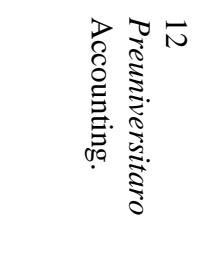 & 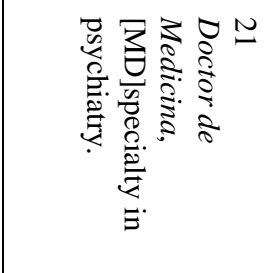 & 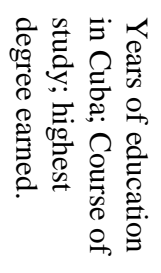 \\
\hline 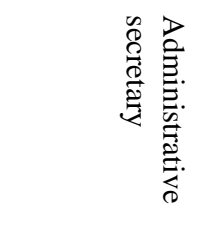 & 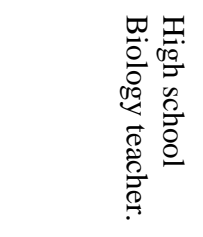 & 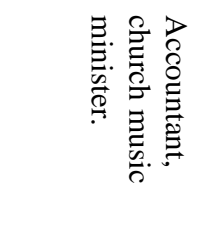 & 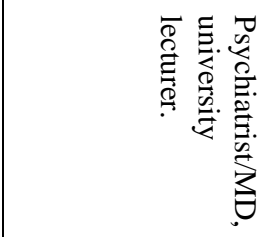 & 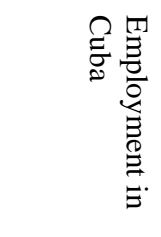 \\
\hline 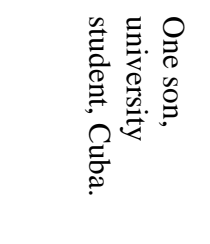 & 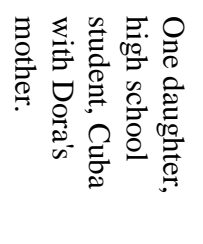 & 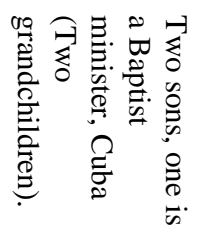 & 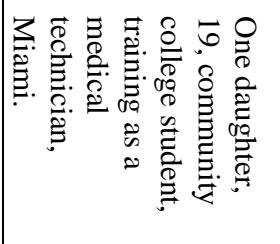 & 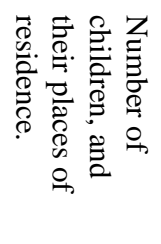 \\
\hline 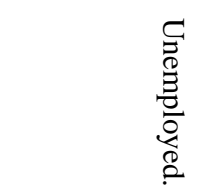 & 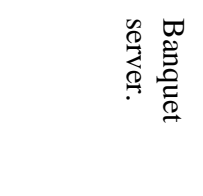 & 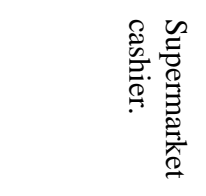 & 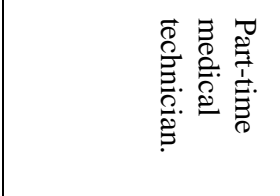 & 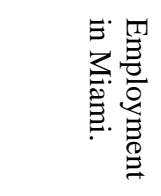 \\
\hline
\end{tabular}


$\underline{\text { Angelica } ・ ~ " P a r a ~ i n t e g r a r m e . " ~[I n ~ o r d e r ~ t o ~ i n t e g r a t e ~ m y s e l f .] ~}$

Angelica hoped to integrate into her new geographic surrounds. Her perceptions that some of her family members who preceded her to Miami had retained too many Cuban customs and maintained closed minds towards the mainstream U.S. society caused her to resist isolation in the historical exile enclave.

- "...cuando tú vas a una tienda te sientes mal por no saber inglés." [...when you go to the store you feel bad for not knowing English.]

She wished to overcome her insecurities about being in non-Spanish speaking places.

$\underline{\text { Dora } ・ \quad ~ " P a r a ~ g a n a r ~ m a ́ s ~ d i n e r o . " ~[T o ~ e a r n ~ m o r e ~ m o n e y .] ~}$

Dora saw English language acquisition as the key to higher paid employment.

- "Como yo puedo trabajar en mi profesión." [So I can work in my profession]

English was necessary for her to gain her teaching certificate and become a biology teacher again.

Marina - "Hay lugares que llego que me limite el idioma." [There are places I get to where the language limits me.]

Marina was limited by language, but desired to interact with people outside her Spanish-speaking contexts.

- "Defenderme en el idioma." [To explain myself (stand up for my self) in the language.]

- She wanted to know what was going on around her in order to interact with others and state her mind as necessary. 
Damaris - "Tengo ofertas de trabajo y entonces ... porque no sé inglés." [I have job offers and then,..because I don't know English.]

Like Dora, Damaris needed English to re-enter her profession.

- $\quad$ "Saber inglés de respetar de la bandera. Respetar a los gobernantes." [To know English is to respect the flag. To respect the governing powers.]

Knowledge of English was a complement to her emerging feeling of nationalism towards the U.S.

\section{Language Learning Opportunities and Silence}

Most striking among our findings was the learners' silence in most of the ESOL classrooms. By silence, we mean a lack of student-initiated discourse and evidence of original thought in speech and in writing. While the focus of the state curriculum frameworks was purportedly on the women's personal learning goals and interests, underlying institutional needs apparently drove the desired curriculum outcomes. Observations and videotaped evidence revealed the answers to the second question of the study: "What were their classroom opportunities for language learning?"

Following their own cultural patterns of respect for "the teacher" and the authority that that position represented, Angelica, Dora, Marina, and Damaris repeated dialogues, filled in blanks on exercises, and memorized rules and vocabulary lists with little if any opportunity to produce their own original utterances. The following excerpt from field notes illustrates the general pattern of silence for all four learners:

She [Dora] has been sitting for over an hour without moving or speaking; She has not spoken in English since I arrived [1hr.10mins] (Classroom observation notes.).

Only Damaris, a medical doctor and highly educated woman in her home country, broke free of the silence occasionally by writing her own version of grammar rules, in Spanish, and by questioning the teacher when she felt the teacher might have been unclear or in error.

Ms. F explains the rule that applies to verbs and Damaris replies, "Noooo!" and circles the word "nouns" with her pencil. The teacher concedes when Damaris does find the rule in her previous notebook. She orally reviews the rule of third person "-s" endings she has written in Spanish in her notebook, evidence that Damaris works very systematically with rules that she explicitly writes out in her own words. Ms. F accepts her explanation (Classroom observation). 
The participants in the study were kept busy responding to demands from standardized dialogue models, choral repetition, and on-the-spot oral checks that required idealized perfection. We sought to understand opportunities for language learning from the participants' perspectives. Silence was the norm partially because of cultural notions of what classroom behavior should be: "The teacher talks, students listen and speak only when spoken to." Olivo (2003) explains this pervasive pattern in classroom discourse management: "The notion that talk and work are in opposition is rooted in traditional ideologies of teaching, where students are understood to be passive recipients of teachers' knowledge" (p.54). In his study of a high school classroom, Olivo found that opportunities for language use were limited by the teacher's control of learner talk.

Traditional teacher roles notwithstanding, there is also a question of how much the participants themselves reproduced the traditional language learning pedagogy. As Olivo writes, "Students appeared to understand the ways in which their talk was undervalued in the classroom setting" (p. 67). Our data reflected a similar learner stance. During an interview with Dora and her husband, Dora attributed her silence to the rules of her classroom. Three days a week her class of approximately 45 students attended class in the divided auditorium where six other classes met simultaneously. The observation notes recorded many instances when her teachers repeatedly reminded students to speak softly.

John: Yes, I observed you (plural) in class and almost never did you (plural) speak during the class to each other.

Dora: No, you can't speak.

J: Yes, you (plural) were staying silent for the majority of the class period.

D: In the auditorium, you cannot speak.

A learner-centered explanation for the silence, situated in his cultural belief system came from Dora's husband, Raúl, during an interview (in Spanish) with the couple because they were both attending the same class together. Raúl shared a dogmatic view about "correct" student behavior in class that Dora, emphatically nodding her head, seemed to validate.

Raúl: We have a, an elemental rule. In our view, regarding a problem of etiquette, if someone is speaking, most of all a teacher, you should pay attention. If you don't wish to pay attention, you wish to waste your time miserably, well, for that I suggest that you don't go to class. Take up fishing or other pastime.

John: So, one is being rude.

R: Rude.

Dora: Exactly. 
Journal of Praxis in Multicultural Education, Vol. 1, No. 1 [2010], Art. 5

R: I see it as flagrant impoliteness. And an invasion of privacy of the others. When a person is speaking, or a cell phone is ringing, or is making some kind of noise, he is invading the privacy of his classmates. And you are indirectly wasting your classmates' time because you interrupt the teacher, interrupt his attention, and that injures the teacher, the students, and you, too.

The same rule of classroom etiquette must have also applied in the selfcontained classrooms as it had in the open environment of the auditorium. In the classrooms, too, the teachers did most of the talking. The only difference was that the students in the self-contained classroom settings could repeat after the teacher more often and more loudly as part of the lesson exercises. The passive attitude toward learning that Angelica, Dora, Marina, and Damaris shared, appeared to include a cultural construct of expected behavior (Rockhill 1987) based on their reported educational experiences in the Castro-Marxist system in Cuba.

What happened to ideals of communicative and dialogic classrooms (Ehrman \& Dörnyei 1998; Green \& Oxford 1995)? Growing concern about missed opportunities for language learning during the fieldwork emerged from the women's' collective and continued silence in class. While Damaris seemed the exception with her occasional direct questions to the teacher, her assumed role as " la estudiante" [Sp.: student (fem.)] and her perceptions of the authoritative role of "la maestra" [Sp.: teacher (fem.)] did not permit questioning the objectives and teaching methods in her class. With no other model of education within their experience or culture, how could any of the women challenge or resist what they saw as the norm? Any possible shift in the pedagogical paradigm to a discursive, communicative, and cooperative model of English language teaching and learning lay in the hands of the teachers (Gass 1997; Katasse 1994). Faced with many examples of our participants' silence, the overwhelming questions became, "What happened to communicative ESOL teaching?" and, "Why don't the students get to speak?" (Seufert 1999).

The nature of the women's silence was also situated in part within the structure of the curriculum itself. A mismatch of personal needs and state mandate appeared to be an "emic/etic dichotomy." Emic aspects of learning refer to internal influences and interests coming from within an individual, while etic influences constitute those originating from contexts outside the person. Systematically, very few of the state framework competencies addressed personal, emic themes. Lesson content and objectives were imposed on, not elicited from learners, contrary to the recommendations of the state curriculum planners (FL DOE 2001b). Even so, the learners themselves appeared to validate the treatment. They respected both the teachers' roles and the prescribed curriculum frameworks (Bartky 1990).

Nevertheless, the performance-based curriculum failed to provide support for the four women's language learning because it did not hold much personal interest nor did rapid progression through the required benchmarks provide the time necessary for developing communicative competence. The classroom environments provided little evidence of the "personal" in any of the observation field notes or videotaped class sessions because the women's teachers routinely 
followed the prescribed checklist of competencies, rarely linking the content with learners' lives.

Figure 1. Damaris' sole personal reference writing sample

My brother is a meohanie My husband is a ba
My dacegther is a medieal assistanto, and g'w
a doctor

The women did not talk or write about anything connected with their personal lives. Damaris provided the only exception in a written sentence listing the occupations of her immediate family members (Figure 1). Angelica and Marina got to describe one of their classmate's stature, hair length and color and items of clothing. There was no evidence of Dora's use of English except to fill in the blanks of text dialogues or sentences that her teacher wrote on the board (Fig.2). Figure 2. Dora's fill-in-the-blank boxes

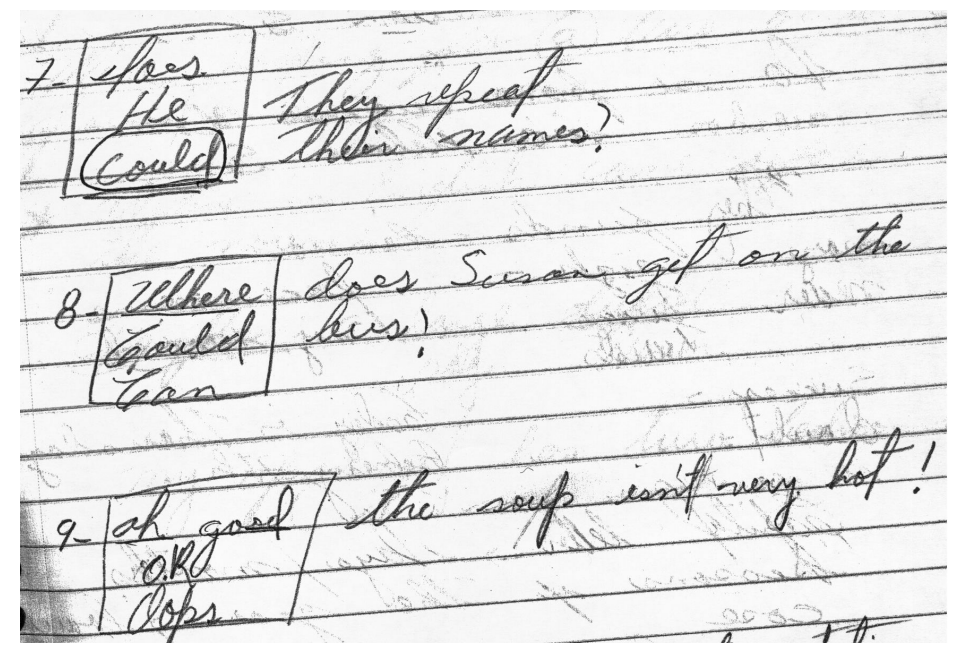

Even so, the four women were generally satisfied with their classroom experiences. Angelica, Dora, Marina, and Damaris collectively expressed a deep faith and trust in the person who embodies the definition of "teacher" (Luttrell 1989).

Learning and Teaching Driven by Assessment

What classroom environmental factors supported their learning opportunities? Generally, the learning environments for our participants were geared toward standardized testing requirements set by state mandates. Findings suggest that performance-based accountability measures, in the experiences of all four women, had a negative influence on the women's classroom opportunities for 
learning spoken and written English because so much of the instructional time was spent on preparation for "the test" by filling out answer sheets, memorizing prospective test content, and practicing test-taking skills. Assessment of their learning was largely based on fill-in-the-blank tests and worksheets that did not address speaking or extended writing.

It became apparent that cooperative and dialogic language learning opportunities succumbed to time constraints rooted in the pressures of completing curriculum checklists and succeeding on norm-referenced, multiplechoice exit tests. Observational data and subsequent analysis led us to conclude that ESOL teaching and learning, at least in the participants' experiences in instructional levels "Literacy Completion Point-A" (LCP-A is the "Foundations" Level of ESOL according to the Florida ADULT ESOL Frameworks) and "Literacy Completion Point-B" (LCP-B is the traditional ESOL Level I), was about getting test items correct. Assessment of learning is an important component in schooling, but it is not and should not be the objective of learning. Furthermore, "evaluation needs to reflect the life-contexts and personal goals of the students" (Purcell-Gates \& Waterman 2000, p. 193). With multiple-choice assessments, Angelica, Dora, Marina, and Damaris simply did not have to speak in order to show they learned the competencies.

The competency checklists themselves were problematic. Many of the competencies could have been satisfied by the worksheets that are easy for teachers to file in the students' assessment portfolios. It is possible that some teachers signed off on completed competencies by assuming the stance of: "I covered it, so the students learned it." Florida adult education researcher Oliva (2002), who examined the same Florida frameworks in her work, concurs in the findings she reports from her quantitative examination of the possible implications of complying with the same state-mandated, performance-based curriculum that framed the participants' ESOL experiences in this study. Teachers, especially part-time instructors, might be influenced by accountability pressures into passing students to the next level in order to earn "literacy completion points" and to keep classes full. The students, according to her findings, suffered the effects of a program that considers earning an LCP more important than actual language learning (p. 17).

In their classrooms, Dora, Angelica, Marina, and Damaris had little opportunity to develop communicative English language skills dialogically and form their own questions about linguistic and cultural aspects of English language use in Miami. They did learn to answer other people's questions and they attempted to do so in perfect form, albeit, "for the test." The four women seemed to learn the prescribed content, stipulated by the state frameworks of LCP-A and LCP-B, which they could talk about in Spanish, but they could not effectively talk about that content in English. By pointing to items or circling "a," "b," or "c," on multiple choice tests and worksheets, they could identify, recognize, and demonstrate lesson content stipulated by the benchmarks. As students, they were satisfied that they had improved themselves by coming to school. They could explain their understanding about the content they learned 
in Spanish, but not in English. The use of checklists based on the curriculum frameworks to measure the women's learning was clearly problematic.

\section{Implications: A Critical Examination of State-Mandated Curriculum} Frameworks

What did the state standards and competencies ask learners to do? In a compilation of all the "Workforce" and" Life Skills" benchmarks in Literacy Completion Points (LCP) levels A and B, 85 out of 134 competencies were stated in lower level behavioral terms (cf. Bloom 1956) such as "identify," "recognize," and "demonstrate." Pointing, answering with one-word responses, or using physical movements could meet the competencies and would be appropriate for Pre-emergence and Early Production stages of second language acquisition. However, learners were not asked to produce longer, original utterances using any higher order thinking skills. In essence, as the competencies were presented, the four women did not have to talk or write to demonstrate their purported language learning. SLA research consensus insists that language learning comes from using the target language in meaningful interaction with other people (Echevarria, et al 2004; Krashen \& Terrell 1983). Yet in the Florida Adult ESOL curriculum frameworks for LCP-A and LCP-B, only 27 out of the 134 competencies require learners to use language, by "defining," "describing," "expressing," "requesting," "setting goals," and, thus to initiate and respond using original and authentic utterances with other people.

There appeared to be two sets of learning and teaching goals operating in Adult ESOL in Florida: (a) learners' goals to learn English, for whatever reason, and (b) the state's need for workers to enter the often low-wage workforce. This tension between the goals of learners and the needs of the state was documented in the official technical assistance paper that the Department of Education had prepared for administrators and instructors (FL DOE 2000). In one place, the technical assistance paper stated that, for the ESOL program to be successful, the goals of students must align with the intent of the state-mandated curriculum, a proviso that seemed to override student goals that fall outside vocational or consumer-based frameworks.

Since the legislature clearly had a vision that all adult education should enhance workforce development, the curriculum frameworks for the Adult ESOL program courses have been developed to reach that goal (p. 13).

A few pages later, the paper exhorted teachers to respond to students' motivation as much as possible. "The targeted level of English proficiency, the content of instruction and its sequencing should be determined by the goals of the students" (p. 15). The reasons may not be in conflict for some learners; nevertheless, the same set of "needs" is routinely generalized and imposed on the entire population of ESOL students. Could it be that the state's interests involved channeling newly arrived immigrant women into low wage jobs such as child care?

Rockhill and Tomic (1995) write that ESL instruction is not so much about language teaching and learning as about instruction in state expectations 
of what constitutes learners' needs - needs prescribed by others. Are such prescribed "needs" authentic and valid for individual learners? The focus is not upon integrating English into the lives of diverse populations of immigrants, "but upon using ESL as a tool for bringing those populations into the [White] Canadian mainstream" (p. 218). Likewise, almost all of the competencies taught in the four women's classrooms had to do with integrating into a power system (employment, health care, U.S. social constructions of personal hygiene, childcare, etc.). Upon review, the Florida standards and competencies as well as the ambivalence to learners' own goals began to make more sense. Would the four women's experiences in adult ESOL instruction assist their language learning according to their maternal, integrational, and professional interests? The mismatch became obvious.

Very few of the competencies were personal or asked a learner to produce language from within her own experience, beliefs, emotions, or goals. Did Angelica, Dora, Marina, and Damaris think that they themselves were, by the written official statement, instrumental in their own needs assessment? Could they see themselves in the schooling context empowered with such decision making (Bartky 1990)? From the government side, it would be incongruent to think of students as empowered to negotiate their own goal decisions with instructors while the frameworks demanded these same students invest in a power structure that treated them as potential labor. From the learners' side, they responded passively to the teachers (and school) as figures of sage authority.

\section{Limitations of the Study}

The findings reflect only the experiences of Angelica, Dora, Marina, and Damaris who attended classes taught by a total of eight teachers. Their learning took place at one adult education center. As with all case studies, the research was limited to the contexts of these participants. A case study researcher can only hope that the conclusions of such a study will generate implications for practice in other classroom contexts. The four women were unique individuals, but they shared several personal aspects - maternity, matrimony, and middle age. A greater range in ages and marital status could have broadened the results of the study. The body of data collected during classroom activities of the participants' first two trimesters of ESOL was sufficient for analysis, but the study would have benefited from more opportunities to collect data and from a wider circle of sources that might have included home contexts. Throughout the fieldwork, the women spoke about their lives, their husbands, and their children; however, more detailed data about their family would have enriched the study. Additionally, the focus of the study centered on the learners' perspectives, not on the teachers'.

Also in naturalistic research, it could be expected that a participant might withdraw from school and, thus, the study. The small number of participants became another kind of limitation when two of them left the school before the data collection concluded. We were able to maintain contact with Marina after she decided, because of domestic pressures and worries about her 
sons in Cuba, not to return to school after the first trimester. However, Angelica's sudden and unexplained departure at the beginning of the second trimester remained a mystery. She moved out of the area but left no forwarding address. Angelica's common Spanish surname made it impossible to locate her.

\section{Recommendations and Conclusions}

The learning opportunities for the four participants could have been enhanced in several ways. Learners would be more engaged in the instructional activities if the curriculum competencies were more closely aligned to the personal needs and goals of learners, rather than to the prescribed ideals of institutional labor interests. Learners would benefit from a more communicative teaching and learning style wherein they could, at times, practice actual language that they actively produced, rather than passively mimicking the words written on the pages of a textbook or mouthed by an instructor.

The beginning ESOL experiences of Angelica, Dora, Marina, and Damaris could have been enriched by more personalized learning aligned to their needs and interests through deeper understanding of the women's social contexts. Their opportunities to learn might have been broader and more fruitful if they had been able to develop their own voices in English, helped shape the strategies for their own learning, and used their new language for their own real purposes. 


\section{References}

Anzaldúa, G. (1997) La frontera/Borderlands. San Francisco: Auntie Lute Books.

Bartky, S. L. (1990). On psychological oppression. In S.L. Bartky, (Ed.), Studies in the phenomenology of oppression. New York: Routledge.

Bem, S. (1993) The Lenses of Gender. New Haven: Yale University Press.

Bloom, B. S. (1956). Taxonomy of educational objectives: The classification of educational goals. New York: David McKay.

Boyd, M. (2001). Gender, refugee status and permanent settlement. Peace Research Abstracts 38(2).

Butler, J. (1993) Bodies that matter: On the discursive limits of sex. New York \& London: Routledge.

Cole, M. (1996). Cultural psychology: A once and future discipline. Cambridge, MA: The Belknap Press of Harvard University Press.

Cummins, J. (1983). Language and literacy learning in bilingual instruction [Policy report]. Austin, TX: Southwest Educational Development Laboratory.

Dörnyei, Z. (2001). Teaching and researching motivation. Harlow, Essex, UK: Pearson Education Ltd.

Echevarria, J, Vogt, M, \& Short, D. (2004) Making content comprehensible for English learners: The SIOP Model. Boston: Pearson.

Ehrman, M. E. \& Dörnyei, Z. (1998). Interpersonal dynamics in second language education: The visible and invisible classroom. Thousand Oaks, CA: Sage.

Espín, O. M. (1999). Women crossing boundaries: A psychology of immigration and transformations of sexuality. New York: Routledge.

Florida Department of Education, Division of Workforce Education (2001a). Florida Adult English for Speakers of Other Languages Checklist, 2001. Available: http://www.firn.edu/doe/workforce/adult_ck.htm Nov. 2002

Florida Department of Education, Division of Workforce Education (2001b). Technical assistance paper for adult ESOL. Tallahassee, Florida: Department of Education. Available: http://www.firn.edu/doe/workforce/adult ed.htm Nov. 2002

García, M. C. (1996). Havana USA. Berkeley: Univ. of California Press.

Gass, S. M. (1997). Input, interaction, and the second language learner. Mahwah, NJ: Lawrence Earlbaum Associates, Publishers.

Gomez, S. V. (2000). Beyond the walls of the household: Gender and adult education participation. In Paul Bélanger \& Albert Tuijnman (Eds.), New patterns of adult learning: A six-country comparative study. New York: Pergamon \& Unesco Institute for Education. Ch. 9, 209-227.

González, J. (1997). A pesar de todo: Nostalgias $Y$ relfexiones sobre la mujer cubana en el exilio. Miami: Ediciones Universal.

Green, J. M. \& Oxford, R.L. (1995). A closer look at learning strategies, L2 proficiency, and gender. TESOL Quarterly, 29(2), 261-297.

Guerra, L. (2001). Race and gender in a "classless" society. Presentation. CUBA: Past History, Present Realities, Future Possibilities. A NAFSA Country/Culture Workshop. Harvard University, March 2001.

Hayes, E. \& Flannery, D. D. (Eds.) (2001). Women as learners. San Francisco: JosseyBass Publishers.

Isasi-Díaz, A. M. (1996). Mujerista theology. Maryknoll, NY: Orbis Books

Katasse, C. (1994). Women's learning strategies for ESL: An exploratory interview study. Doctoral dissertation. The Union Institute. 
Klassen, C. (1987). Language and literacy learning: An adult immigrant's account. Unpublished Masters thesis, Ontario Institute for Studies in Education/University of Toronto, Canada.

Krashen, S. D. (1981). Second language acquisition and second language learning. New York: Pergamon Press.

Krashen, S. \& Terrell, T. (1983). The natural approach: Language acquisition in the classroom. Oxford: Pergamon.

Lindors, J.W. (1999). Children's inquiry: Using language to make sense of the world. New York: Teachers College Press

Losey, K. M. (1995). Gender and ethnicity as factors in the development of verbal skills in bilingual Mexican American women. TESOL Quarterly 29(4), 635-663.

Luttrell, W. (1989). Working-class women's ways of knowing: Effects of gender, race, and class. Sociology of Education 62, 33-46.

McCracken, G. (1988) The long interview. Newbury Park, CA: Sage.

McDonough J. \& McDonough, S. (1997) Research methods for English language teachers. London: Arnold.

Menard-Warwick, J. (2005) Intergenerational trajectories and sociopolitical context: Latina immigrants in adult ESL. TESOL Quarterly 39(2) June 2005 pp. 165185.

Norton-Peirce, B. (1995). Social identity, investment, and language learning. TESOL Quarterly 29(1), 9-34.

Oliva, M. (2002). Effective methods for the collection of Literacy Completion Points in Miami-Dade County. Doctoral practicum report. Nova Southeastern University.

Olivo, W. (2003) "Quit talking and learn English!": Conflicting langiage ideologies in an ESL classroom. Anthropology \& Education Quarterly 34(1) pp. 50-71. American Anthropological Association.

Peck, T.A. (1986). Women's self-definition in adulthood: From a different model? Psychology of Women Quarterly. 10, 274-284.

Portes, A. \& Bach, R. L. (1985). Latin journey: Cuban and Mexican immigrants in the United States. Berkeley: University of California Press.

Purcell-Gates, V. \& Waterman, R.A. (2000). Now we read, we see, we speak: Portrait of literacy development in an adult Freirean-based class. Mahwah, N.J.: L. Erlbaum Associates, Publishers.

Rochkill, K. (1987). Gender, language and the politics of literacy. British Journal of Sociology in Education. 8(2), 153-168.

Rockhill, K. \& Tomic, P. (1995) " Situating ESL between speech and silence." In Jane Gaskell \& John Willinsky (Eds.), Gender in/forms curriculum: From enrichment to transformation. New York: Teachers College Press. Ch. 8, 209229.

Rogg, E. M. (1974). The Assimilation of Cuban exiles: The role of community and class. New York: Federal Legal Publications.

Saldaña, D.H. (1992). Coping with stress: A refugee's story. In Ellen Cole, Oliva M. Espín, \& Esther D. Rothblum (Eds.), Refugee women and their mental health: Shattered societies, shattered lives. New York: Harrington Park Press. 21-34.

Schwarte, B. (2001). The role of gender in language learning and teaching. Address to TESOL, St. Louis, MO. March 31, 2001.

Seufert, P. (1999). Refugees as English language learners: Issues and concerns. National Clearinghouse for ESL Literacy Education. Washington, D.C.: Center for Applied Linguistics.

Spradley, J. P. (1979). The ethnographic interview. Ft. Worth: Harcourt Brace College Publishers. 
Tisdell, E. J. (1993). Feminism and adult learning: Power, pedagogy, and praxis. New Directions for Adult Learning and Continuing Education. 57, Sp. 1993. Jossey-Bass Publishers.

Townsend, J.S. \& Fu, D. (2001). Paw's story: A Laotian refugee's lonely entry into American literacy. Journal of Adolescent \& Adult Literacy 45(2), 2-12.

Zentella, A. C. (1997). Growing up bilingual: Puerto Rican children in New York. Cambridge, MA: Blackwell.

Zolberg, A.R., Suhrke, A. \& Aguayo, S. (1989). Escape from violence: Conflict and the refugee crisis in the developing world. New York: Oxford University Press. 